\title{
Hypothesis
}

\section{Insulinotropic Effects of Hypoglycaemic and Hyperglycaemic Sulphonamides: The Ionophoretic Hypothesis}

\author{
E. Couturier and W. J. Malaisse \\ Laboratory of Experimental Medicine, Brussels Free University, Brussels, Belgium
}

\begin{abstract}
Summary. Hypoglycaemic sulphonamides stimulate net uptake of ${ }^{45} \mathrm{Ca}^{++}$and insulin release in isolated pancreatic islets. These effects are antagonized by organic calcium-antagonists (e.g. suloctidil). In an artificial system, hypoglycaemic sulphonamides, such as gliclazide, stimulate the translocation of calcium into or across a hydrophobic immiscible domain, a process enhanced by the antibiotic ionophore A 23187 and antagonized by suloctidil. In this artificial system, the A 23187-mediated process of calcium countertransport is stimulated by gliclazide and inhibited by diazoxide. It is postulated that the insulinotropic action of hypoglycaemic and hyperglycaemic sulphonamides is primarily attributable to the ionophoretic action of these drugs.
\end{abstract}

Key words: Hypoglycaemic sulphonylureas, diazoxide, calcium, insulin release, ionophores, organic calcium antagonists.

Hypoglycaemic sulphonylureas stimulate insulin release from the pancreatic $B$-cell. The mechanism of such an insulinotropic effect is poorly understood [1]. Within the framework of current concepts concerning the cytophysiology of insulin release [2], three primary sites of action could be proposed to account for the insulinotropic action of sulphonylureas: a facilitation of nutrient metabolism, an interference with cyclic AMP synthesis or breakdown, or a remodelling of ionic fluxes in the B-cell.

Biochemical studies, reviewed elsewhere $[1,3]$, do not support the first of these 3 hypotheses.

Although hypoglycaemic sulphonylureas were occasionally claimed to activate adenylate cyclase [4] and repeatedly found to inhibit phosphodiesterase
[5-7] in islet homogenates, the relevance of the latter finding may be questioned since sulphonylureas apparently do not penetrate the B-cell beyond the plasma membrane [1]. A drug-induced increase in the cyclic AMP content of intact islets could be secondary to a cytosolic accumulation of $\mathrm{Ca}^{2+}[8]$.

The third hypothesis, namely that of a primary action of hypoglycaemic sulphonylureas upon ionic movements, may involve two distinct mechanisms. First, sulphonylureas may cause a decrease in $\mathrm{K}^{+}$ conductance $[9,10]$ leading to subsequent cell depolarization and gating of voltage-dependent $\mathrm{Ca}^{2+}$ channels; however, under suitable conditions, tolbutamide is able to stimulate $\mathrm{Ca}^{2+}$ influx and insulin release without decreasing $\mathrm{K}^{+}$conductance [11]. Second, sulphonylureas may directly interfere with an ionophoretic modality of $\mathrm{Ca}$ transport across the B-cell plasma membrane [12-15]. This hypothesis has recently been scrutinized in great detail [16-18].

The present report documents some selected experimental findings in support of the ionophoretic hypothesis.

\section{Methodological Considerations}

Insulin release was measured in groups of 8 pancreatic islets, removed from fed female albino rats and incubated for $60 \mathrm{~min}$ at $37^{\circ} \mathrm{C}$ in a bicarbonate-buffered solution [19]. The net uptake of ${ }^{45} \mathrm{Ca}^{2+}$ by the islets was measured over 90 min incubation, followed by repeated washes of the islets in order to remove extracellular radioactivity [20].

Two methods were used to characterize the ionophoretic capacity of sulphonylureas and other drugs. In the first method, a small volume $(0.2 \mathrm{ml})$ of a Hepes- $\mathrm{NaOH}$ buffer $(25 \mathrm{mmol} / \mathrm{l} ; \mathrm{pH} 7.0)$ containing $\mathrm{Na}^{+} 125, \mathrm{~K}^{+} 5$ and $\mathrm{Cl}^{-} 120 \mathrm{mmol} / \mathrm{l}$ and ${ }^{45} \mathrm{Ca}$ 


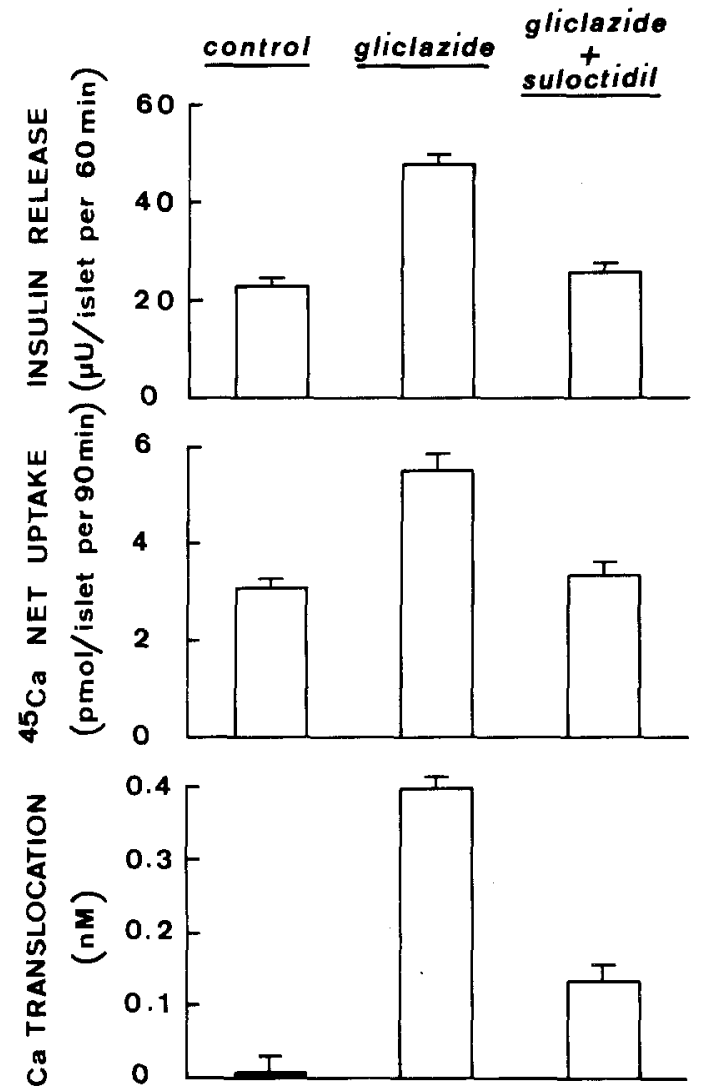

Fig. 1. Effect of gliclazide $(62 \mu \mathrm{mol} / \mathrm{l})$ and suloctidil $(5 \mu \mathrm{mol} / \mathrm{l})$ upon insulin release (upper panel; $\mathrm{n}: 13$ ) and ${ }^{45} \mathrm{Ca}$ net uptake (middle panel; $\mathrm{n}: 39-57$ ) by isolated islets incubated in the presence of $5.6 \mathrm{mmol} / \mathrm{l}$ glucose. The translocation of calcium from an aqueous Hepes buffer $(25 \mathrm{mmol} / 1$; $\mathrm{pH} 7.0)$ containing $\mathrm{Na}^{+} 125$, $\mathrm{K}^{+} 5$ and $\mathrm{Cl}^{-} 120 \mathrm{mmol} / 1$ and ${ }^{45} \mathrm{Ca}(1.4 \mathrm{umol} / 1)$ into an organic phase (toluene/butanol, $7 / 3, \mathrm{v} / \mathrm{v}$ ) containing, as required, gliclazide alone $(3.0 \mathrm{mmol} / \mathrm{l})$ or in combination with suloctidil $(0.3 \mathrm{mmol} / \mathrm{l})$ is expressed as the concentration of calcium of the organic phase (lower panel; $\mathrm{n}=3$ ). The stimulant action of gliclazide and the inhibitory effect of suloctidil upon gliclazidestimulated processes were highly significant $(\mathrm{P}<0.001)$ in all cases. Note that the molar ratio of gliclazide/suloctidil (10-12) was comparable in the experiments performed with pancreatic islets and the artificial system, respectively

$(1-10 \mu \mathrm{mol} / \mathrm{l})$ was vigorously mixed for $1 \mathrm{~min}$ at room temperature with an equal volume of a mixture of toluene/butanol $(7 / 3, \mathrm{v} / \mathrm{v})$. An aliquot $(0.1 \mathrm{ml})$ of the supernatant immiscible organic phase was then examined for its readioactive content by liquid scintillation [21]. In the second method [22], $0.15 \mathrm{ml}$ of an organic mixture (toluene/butanol, $7 / 3, \mathrm{v} / \mathrm{v}$ ) containing A $23187(0.1 \mathrm{mmol} / \mathrm{l})$ and, as required, gliclazide $(16 \mathrm{mmol} / \mathrm{l})$ or diazoxide $(22 \mathrm{mmol} / 1)$ was transferred back and forth between two tubes each containing $0.30 \mathrm{ml}$ of aqueous medium and $0.05 \mathrm{ml}$ of the same organic mixture. The two aqueous media consisted of a triethanolamine- $\mathrm{HCl}$ buffer $(20 \mathrm{mmol} /$ 1 ; pH 7.0) containing $0.2 \mathrm{mmol} / 1 \mathrm{CaCl}_{2}\left({ }^{40} \mathrm{Ca}\right.$ and

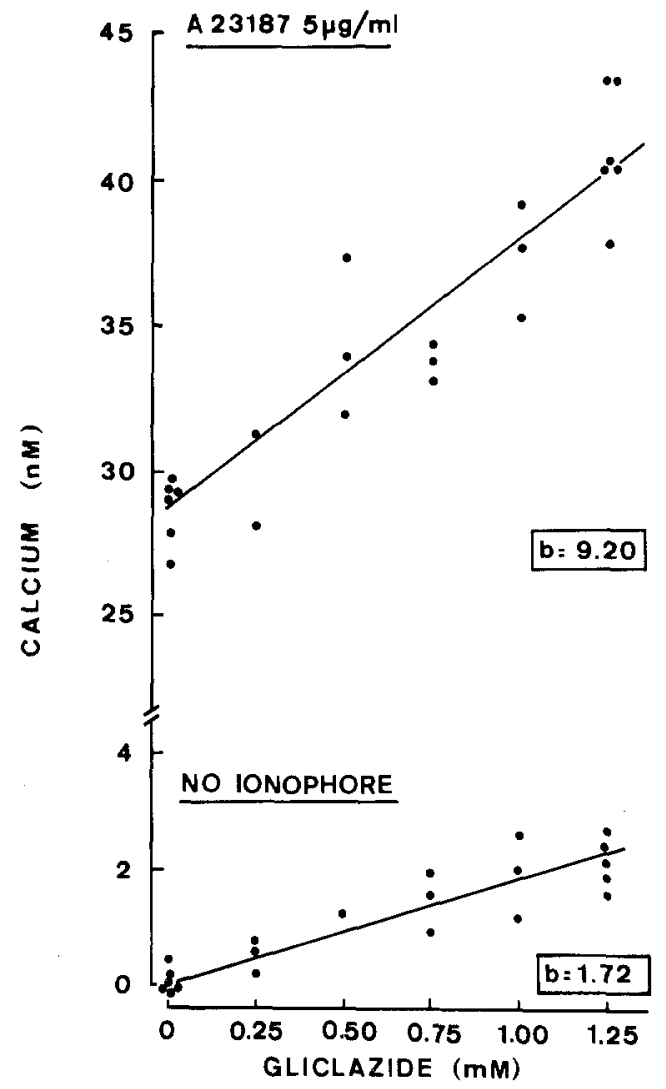

Fig. 2. Effect of gliclazide and the antibiotic ionophore A23187 upon calcium translocation into an organic phase. The initial aqueous phase consisted of a Hepes buffer $(25 \mathrm{mmol} / \mathrm{l} ; \mathrm{pH} 7.0)$ containing $\mathrm{Na}^{+} 125, \mathrm{~K}^{+} 5$ and $\mathrm{Cl}^{-} 120 \mathrm{mmol} / \mathrm{l}$ and ${ }^{45} \mathrm{Ca}(10 \mu \mathrm{mol} / \mathrm{l})$. The initial organic phase consisted of a toluene/butanol mixture $(7 / 3, v / v)$. Gliclazide was added to the aqueous phase and A23187 to the organic phase, at the stated concentration. The Ca concentration of the final organic phase is shown as a function of the concentration of gliclazide. The slope of the regression line (b) was much higher $(\mathrm{P}<0.001)$ in the presence of A23187 (upper line) than in its absence (lower line). Note the change in both elevation and relative scale of the 2 segments of the ordinate axis

${ }^{45} \mathrm{Ca}$ ) and either 2 or $200 \mathrm{mmol} / \mathrm{l} \mathrm{LiCl}$. After each transfer, the aqueous medium and organic phase were vigorously mixed for $1 \mathrm{~min}$. Samples were removed from the aqueous media after each two back-and-forth transfers of the organic phase, and examined for their radioactive content. In these experiments, $\mathrm{a} \mathrm{Li}^{+}$gradient was used because A 23187 is able to mediate $\mathrm{Li}-\mathrm{Ca}$ but not $\mathrm{Na}-\mathrm{Ca}$ countertransport [22].

All results are expressed as the mean ( \pm SEM) together with the number of individual observations. The statistical significance of differences between mean values was estimated by use of Student's $t$ test. 


\section{Stimulation by Hypoglycaemic Sulphonylureas of $\mathrm{Ca}$ Entry and Net Uptake in Isolated Islets}

Figure 1 illustrates that gliclazide, like other hypoglycaemic sulphonylureas $[3,23]$, stimulates ${ }^{45} \mathrm{Ca}$ net uptake and insulin release from isolated islets. The time course $[3,23]$ and dose-action relationship [24] for the sulphonylurea-induced increase in ${ }^{45} \mathrm{Ca}$ net uptake, as well as its modulation by the ambient concentration of glucose, coincide with the time course and magnitude of the drug-induced increment in insulin release.

The capacity of hypoglycaemic sulphonylureas to stimulate Ca entry into the islet cells is documented by the observation that these agents provoke a dramatic and immediate increase in ${ }^{45} \mathrm{Ca}$ efflux from prelabelled islets and also by the abolition of this effect in the absence of extracellular $\mathrm{Ca}^{2+}$ [25], indicating that it corresponds to a process of $\mathrm{Ca}-\mathrm{Ca}$ exchange between the influent ${ }^{40} \mathrm{Ca}$ and effluent ${ }^{45} \mathrm{Ca}$ [26]. The mechanism by which hypoglycaemic sulphonylureas stimulate $\mathrm{Ca}$ influx into the islet cells is the major theme of the present work.

\section{Ionophoretic Effects} of Hypoglycaemic Sulphonylureas

As illustrated in Figure 2, gliclazide is able to translocate $\mathrm{Ca}^{2+}$ from an aqueous solution into an organic phase chosen to mimic the hydrophobic domain of the plasma membrane. Further studies reported in detail elsewhere [16] allowed us to characterize the ionophoretic effect of hypoglycaemic sulphonylureas as follows. Over a much wider range of concentrations than that used in Figure 2, the amount of $\mathrm{Ca}^{2+}$ translocated into the organic phase was proportional to the square of the drug concentration, suggesting a $2 / 1$ stoichiometry for the interaction between $\mathrm{Ca}^{2+}$ and the sulphonylureas. At increasing concentrations of $\mathrm{Ca}^{2+}$ in the initial aqueous phase, the phenomenon of $\mathrm{Ca}^{2+}$ translocation appeared as a saturable phenomenon. It was inhibited in a dose-related fashion by increasing concentrations of $\mathrm{Na}^{+}$or $\mathrm{H}^{+}$. Tolbutamide and gliclazide also provoked $\mathrm{Na}^{+}$translocation into the organic phase, the amount of $\mathrm{Na}^{+}$ translocated being proportional to the drug concentration [16].

All hypoglycaemic sulphonamides examined for such a purpose (i.e., tolbutamide, glycodiazin, gliclazide, glisoxepide, glipizide and glibenclamide) were able to translocate $\mathrm{Ca}^{2+}$, whereas nonhypoglycaemic derivatives of either gliclazide or glipizide were unable to do so. Hypoglycaemic sulphonylureas were also able to provoke the translocation of ${ }^{45} \mathrm{Ca}$ from one aqueous medium into another across the organic mixture [16]. The concentrations of sulphonylureas used in these experiments were not higher than those presumed to be found in the phospholipid domain of the B-cell plasma membrane when pancreatic islets are exposed to the same extracellular concentration of the drug as that used in most in vitro studies, this estimation taking into account the reported values for the uptake of hypoglycaemic sulphonylureas by isolated islets [1].

\section{Combined Effect of Hypoglycaemic Sulphonylureas and Antibiotic Ionophores}

The effect of hypoglycaemic sulphonylureas in causing $\mathrm{Ca}$ translocation into the organic phase is relatively modest at near-physiological $\mathrm{Ca}^{2+}$ concentration in the aqueous phase [16]. This is due to a relatively low affinity of hypoglycaemic sulphonylureas, so that saturation of their ionophoretic capacity (i.e. translocation of one $\mathrm{Ca}$ atom for each two molecules of drug present in the organic phase) requires much higher $\mathrm{Ca}^{2+}$ concentrations [16].

The gliclazide-induced increment in Ca translocation is dramatically enhanced when the drug is used in combination with the antibiotic ionophore A 23187 (Fig. 2). Such a cooperativity between distinct ionophoretic molecules, which is not an exceptional phenomenon [27], represents an important feature of the present hypothesis. Indeed, the sulphonylureas may be better able to affect $\mathrm{Ca}$ transport across membrane systems in the B-cell when acting in synergism with native ionophores [28]. Moreover, when hypoglycaemic sulphonylureas and other ionophoretic molecules (e.g., A 23187 or X 537 A) are used in combination, the transport of divalent cations is affected preferentially relative to that of monovalent cations. For instance, the combined use of $\mathrm{X} 537 \mathrm{~A}$ and gliclazide, which are both able to translocate $\mathrm{Na}$ and $\mathrm{Ca}$ into the organic phase when used separately, results in a synergistic effect upon the translocation of $\mathrm{Ca}$, but not that of $\mathrm{Na}$ [17]. This dissociated behaviour is not surprizing, since the translocation of $\mathrm{Na}$, as distinct from that of $\mathrm{Ca}$, corresponds to a $1 / 1$ stoichiometry for the interaction between $\mathrm{Na}$ and either X537A or gliclazide $[16,29]$.

\section{Inhibition by Organic Calcium-Antagonists of Gliclazide's Action}

Organic calcium-antagonists such as verapamil, D 600, nifedipine and suloctidil inhibit insulin release evoked by a variety of secretagogues such as glucose, $\alpha$-ketoisocaproate, $\mathrm{Ba}^{2+}$ and extracellular $\mathrm{Ca}^{2+}$ in high concentrations [30-36]. The primary mode of action of the calcium-antagonists is to inhibit $\mathrm{Ca}^{2+}$ 
entry into the islet cells [37]. The finding that verapamil also abolishes A23187-induced insulin release led us to postulate that the organic antagonist interacts with a $\mathrm{Ca}^{2+}$-binding site common to both A23187 and the native ionophore, located at the Bcell membrane [38]. The latter concept was indeed validated, in the artificial system, using either A23187 [39] or native ionophoretic material extracted from isolated islets [28]. Further analogies between the artificial system and intact cells include a competitive protective effect of $\mathrm{Ca}^{2+}$ itself against the inhibitory action of verapamil [40] and the existence of a significant rank correlation between the relative efficiency of chemically-related drugs to inhibit $\mathrm{Ca}$ translocation into the organic phase and $\mathrm{Ca}^{2+}$-dependent biological processes, respectively [41].

With this knowledge in mind, the fact that organic calcium-antagonists also inhibit ${ }^{45} \mathrm{Ca}$ net uptake and insulin release evoked by hypoglycaemic sulphonylureas in isolated islets $[37,42]$ is not surprising and, at first glance, does not throw much light on the mode of action of the hypoglycaemic agents. However, the finding illustrated in Figure 1 that suloctidil, in addition to inhibiting ${ }^{45} \mathrm{Ca}$ net uptake and insulin release in the islets, also inhibits gliclazide-mediated $\mathrm{Ca}$ translocation in the artificial system reveals a direct interference of the organic calcium-antagonist with the ionophoretic effect of gliclazide. Such a direct interference may explain why organic calciumantagonists, at a given concentration, are better able to inhibit ${ }^{45} \mathrm{Ca}$ net uptake in islets exposed to hypoglycaemic sulphonylureas than in islets stimulated with glucose $[37,42]$.

Further experiments have indicated that the dose-action relationship for the inhibitory effect of suloctidil upon gliclazide- or tolbutamide-mediated $\mathrm{Ca}$ translocation displays the same features as those found with other ionophores [16], e.g., A23187. This similarity is important, since the dose-action relationship, when examined at various $\mathrm{Ca}^{2+}$ concentrations, allows the demonstration of competition between $\mathrm{Ca}^{2+}$ and its antagonist for a common site on the ionophoretic molecule [41].

\section{Opposite Effects of Hypoglycaemic and Hyperglycaemic Sulphonamides upon Ionophore-mediated Calcium Transport}

The data so far presented in this report refer to the ionophoretic capacity of hypoglycaemic sulphonylureas. The hyperglycaemic sulphonamide diazoxide, which inhibits ${ }^{45} \mathrm{Ca}$ net uptake and insulin release in isolated islets [20], exerts no major effect upon ${ }^{45} \mathrm{Ca}$ translocation in the two phase-system, whether in the presence or absence of antibiotic ionophores [16,
17]. The capacity of diazoxide to translocate $\mathrm{Ca}$ across the organic phase in the three phase-system is also negligible compared to that of gliclazide or tolbutamide [16, 18].

Opposite effects of hypoglycaemic and hyperglycaemic sulphonylureas, respectively, upon ionophore-mediated calcium transport were observed, when investigating the influence of these agents upon $\mathrm{Na}-\mathrm{Ca}$ or $\mathrm{Li}-\mathrm{Ca}$ countertransport. In this countertransport process, $\mathrm{Ca}^{2+}$ is transported by ionophores against its own chemical gradient and across the organic phase, provided that a suitable ion $\left(\mathrm{Na}^{+}\right.$, $\mathrm{Li}^{+}$) is distributed asymmetrically, so that the downhill flux of $\mathrm{Na}^{+}$or $\mathrm{Li}^{+}$is coupled with the uphill transport of $\mathrm{Ca}^{2+}$ in the opposite direction $[22,43]$. Hypoglycaemic sulphonylureas are themselves able to mediate such a countertransport [18]. Diazoxide is unable to do so and does not affect sulphonylureamediated countertransport [18]. Gliclazide acts synergistically with A23187 in the process of countertransport, whereas diazoxide inhibits A23187-

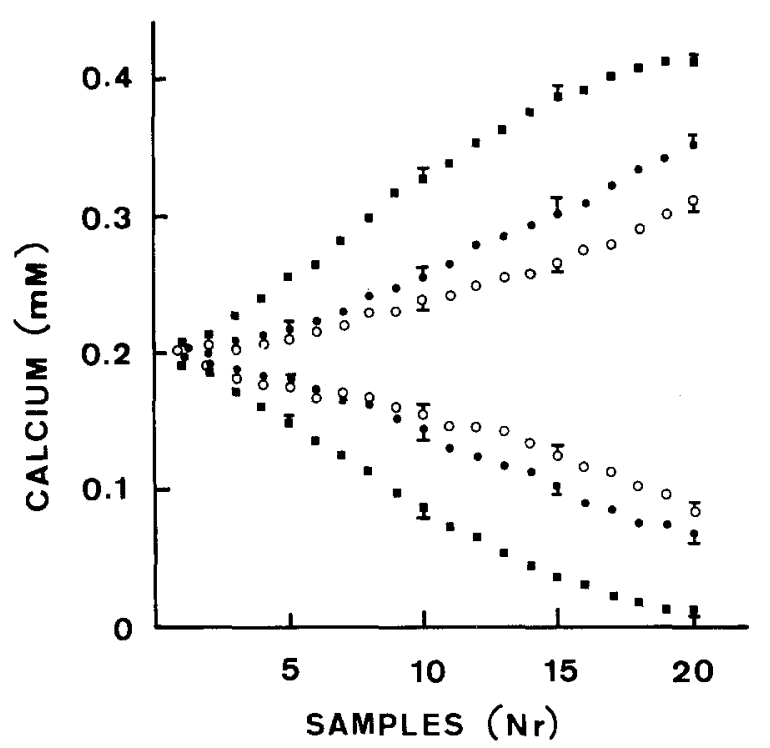

Fig. 3. Effect of gliclazide and diazoxide upon A23187-mediated $\mathrm{Li}$-Ca countertransport. At time zero, $0.3 \mathrm{ml}$ of a triethanolamine$\mathrm{HCl}$ buffer $\left(20 \mathrm{mmol} / \mathrm{l}\right.$; pH 7.0 ) containing $0.2 \mathrm{mmol} / 1 \mathrm{CaCl}_{2}$ $\left({ }^{40} \mathrm{Ca}\right.$ and $\left.{ }^{45} \mathrm{Ca}\right)$ and either $2 \mathrm{mmol} / \mathrm{l}$ (descending curves) or $200 \mathrm{mmol} / 1$ (ascending curves) $\mathrm{LiCl}$ was placed in each of two chambers. An organic immiscible phase $(0.2 \mathrm{ml}$; toluene/butanol, $7 / 3, \mathrm{v} / \mathrm{v})$ containing A23187 $(0.1 \mathrm{mmol} / \mathrm{l})$ and, as required gliclazide $(16 \mathrm{mmol} / \mathrm{l})$ or diazoxide $(22 \mathrm{mmol} / \mathrm{l})$ was transferred back-and-forth from one chamber to the other and thoroughtly mixed for $1 \mathrm{~min}$ with the aqueous medium. Samples were removed from the aqueous media after each two back-and-forth transfers of the organic phase to establish their $\mathrm{Ca}^{2+}$ concentration. Mean values $( \pm \mathrm{SEM})$ refer to 3 separate experiments in each case. Note that gliclazide squares facilitated and diazoxide (open circles) inhibited $\mathrm{Li}$-Ca countertransport, relative to the control values found with A23187 alone (closed circles) 
mediated countertransport (Fig. 3). When both sulphonamides are used in combination with A23187, the results are not significantly different from those seen when only gliclazide is present together with A23187 [18]. Comparable results were obtained when native ionophores extracted from the islets were used instead of A23187 in this system [18].

These data add considerable support to the ionophoretic hypothesis here under consideration. They indeed reveal that the well known opposite effects of hyperglycaemic and hypoglycaemic sulphonylureas, respectively, upon ${ }^{45} \mathrm{Ca}$ net uptake [20, 23], ${ }^{45} \mathrm{Ca}$ efflux [25] and insulin release can be mimicked in the artificial system. Moreover, there are similarities with intact B-cells [44] where the inhibitory effect of diazoxide is suppressed and the stimulant action of gliclazide remains unaffected when both sulphonamides are used in combination.

\section{Conclusion}

The data presented in this report suggest that the ionophoretic capacity of hypoglycaemic and hyperglycaemic sulphonamides may play an important role in the expression of their insulinotropic action. Studies using more sophisticated models of artificial membranes are in progress in order to characterize further the influence of these drugs upon ion transport. Meanwhile, it is proposed that these drugs affect calcium movements in the B-cell, and possibly other organs (e.g. heart and platelets; see $[45,46]$ ), by interference with the process of calcium transport as mediated by native ionophores.

Acknowledgements. We thank Mrs. M. Mahy and C. Demesmaeker for technical assistance and secretarial help. This work was supported by grants from the Belgian Foundation for Scientific Medical Research.

\section{References}

1. Hellman B, Täljedal I-B (1975) Effects of sulfonylureas derivatives on pancreatic B-cells. In: Hasselblatt A, Bruchhausen Ev (eds) Insulin II. Springer, Berlin Heidelberg New York, p 175-194

2. Malaisse WJ, Sener A, Herchuelz A, Hutton JC (1979) Insulin release: the fuel hypothesis. Metabolism 28: 373-386

3. Kawazu S, Sener A, Couturier E, Malaisse WJ (in press) Metabolic, cationic and secretory effects of hypoglycaemic sulfonylureas in pancreatic islets. Naunyn Schmiedebergs Arch Pharmacol

4. Levey GS, Schmidt WMI, Mintz DH (1972) Activation of adenylcyclase in a pancreatic islet cell adenoma by glucagon and tolbutamide. Metabolism 21: 93-98

5. Ashcroft SJH, Randle PJ, Täljedal I-B (1972) Cyclic necleotide phosphodiesterase activity in normal mouse pancreatic islets. FEBS Lett 20:263-266
6. Sams DJ, Montague W (1972) The role of adenosine 3':5'cyclic monophosphate in the regulation of insulin release. Properties of islet-cell adenosine 3':5'-cyclic monophosphate phosphodiesterase. Biochem J 129: 945-952

7. Goldfine ID, Perlman R, Roth J (1971) Inhibition of cyclic 3', 5'AMP phosphodiesterase in islet cells and other tissues by tolbutamide. Nature 234: 295-297

8. Valverde I, Vandermeers A, Anjaneyulu R, Malaisse WJ (1979) Calmodulin activation of adenylate cyclase in pancreatic islets. Science 206: 2225-2237

9. Boschero AC, Malaisse WJ (1979) The stimulus-secretion coupling of glucose-induced insulin release. $X X I X$. Regulation of ${ }^{86} \mathrm{Rb}^{+}$efflux from perifused islets. Am J Physiol 236: E 139-E 146

10. Henquin JC (1980) Tolbutamide stimulation and inhibition of insulin release: studies of the underlying ionic mechanisms in isolated rat islets. Diabetologia 18: 151-160

11. Malaisse WJ, Carpinelli AR, Herchuelz A (in press) Tolbutamide stimulates $\mathrm{Ca}^{2+}$ influx in islet cells without reducing $\mathrm{K}^{+}$conductance. Diabetologia

12. Malaisse WJ, Sener A, Herchuelz A, Hutton JC, Devis G, Somers G, Blondel B, Malaisse-Lagae F, Orci L (1977) Sequential events in the process of glucose-induced insulin release. Excerpta Medica Int Congr Series 413: 95-102

13. Malaisse WJ, Devis G, Hutton JC, Somer's G (1977) Effect of insulinotropic agents on $\mathrm{Ca}^{2+}$ translocation in an artificial system. Diabetes 26: 407

14. Hoek, JC, Corkey BE, Rich TL, Scarpa A, Williamson JR (1978) Sulfonylureas-induced changes in calcium permeability of biological membranes. Diabetes 27: 481

15. Corkey BE (1978) Calcium transport properties of the hypoglycemic sulfonylureas. Fed Proc 37: 1543

16. Couturier E, Malaisse WJ (in press) Ionophoretic activity of hypoglycemic sulfonylureas. Arch Int Pharmacodyn

17. Couturier E, Malaisse WJ (in press) Synergistic effects of hypoglycemic sulfonylureas and antibiotic ionophores upon calcium translocation. Br J Pharmacol

18. Anjaneyulu R, Anjaneyulu K, Couturier E, Malaisse WJ (in press) Opposite effects of hypoglycemic and hyperglycemic sulfonamides upon ionophore-mediated calcium transport. Biochem Pharmacol

19. Malaisse WJ, Brisson G, Malaisse-Lagae F (1970) The stimulus-secretion coupling of glucose-induced insulin release. $I$. Interaction of epinephrine and alkaline earth cations. J Lab Clin Med 76: 895-902

20. Malaisse-Lagae F, Malaisse WJ (1971) Stimulus-secretion coupling of glucose-induced insulin release. III. Uptake of ${ }^{45}$ calcium by isolated islets of Langerhans. Endocrinology 88 : $72-80$

21. Malaisse WJ, Valverde I, Devis G, Somers G, Couturier E (1979) Ionophore-mediated cation translocation in artificial systems. I. A23187-mediated calcium translocation. Biochimie 61: 1185-1192

22. Malaisse WJ, Anjaneyulu K, Anjaneyulu R, Couturier E (1980) Ionophore-mediated $\mathrm{Ca}^{2+}$ countertransport: role of $\mathrm{Na}^{+}, \mathrm{Li}^{+}$or $\mathrm{H}^{+}$gradient. Mol Cell Biochem 30:67-70

23. Malaisse WJ, Mahy M, Brisson GR, Malaisse-Lagae F (1972) The stimulus-secretion coupling of glucose-induced insulin release. VIII. Combined effects of glucose and sulfonylureas. Eur J Clin Invest 2: 85-90

24. Malaisse WJ, Sener A Herchuelz A (1979) Effects of insulinotropic agents on cationic fluxes in islet cells. In: Treatment of early diabetes. Camerini-Davalos RA, Hanover G (eds) Plenum Press, New York, p 85-96

25. Malaisse WJ, Pipeleers DG, Mahy M (1973) The stimulussecretion coupling of glucose-induced insulin release. XII. Effects of diazoxide and gliclazide upon ${ }^{45}$ calcium efflux from perifused islets. Diabetologia 9: 1-5 
26. Herchuelz A, Couturier E, Malaisse WJ (1980) Regulation of calcium fluxes in pancreatic islets: glucose-induced calciumcalcium exchange. Am J Physiol 238: E96-E103

27. Couturier E, Deleers M, Malaisse WJ (in press) Synergism between distinct ionophores. Pharmacol Res Commun

28. Valverde I, Malaisse WJ (1979) Ionophoretic activity in pancreatic islets. Biochem Biophys Res Commun 89: 386-395

29. Couturier E, Malaisse WJ (1980) Ionophore-mediated cation translocation in artificial systems. II. X537A-mediated calcium and sodium translocation. Biochimie 62: 177-180

30. Devis G, Somers G, Van Obberghen E, Malaisse WJ (1975) Calcium-antagonists and islet function. I. Inhibition of insulin release by verapamil. Diabetes $24: 547-551$

31. Malaisse WJ, Devis G, Pipeleers DG, Somers G (1976) Calcium-antagonists and islet function. IV. Effect of D 600 . Diabetologia 12: 77-81

32. Somers G, Devis G, Van Obberghen E, Malaisse WJ (1976) Calcium-antagonists and islet function. VI. Effect of barium. Pflïgers Arch 365: 21-28

33. Malaisse WJ (1977) Calcium-antagonists and islet function. X. Effect of suloctidil. Arch Int Pharmacodyn 228: 339-344

34. Malaisse WJ, Boschero AC (1977) Calcium-antagonists and islet function. XI. Effect of nifedipine. Horm Res 8: 203-209

35. Devis G, Somers G, Malaisse WJ (1975) Stimulation of insulin release by calcium. Biochem Biophys Res Commun 67: 525-529

36. Devis G, Somers G, Malaisse WJ (1977) Dynamics of calciuminduced insulin release. Diabetologia 13: 531-536

37. Malaisse WJ, Herchuelz A, Levy J, Sener A (1977) Calciumantagonists and islet function. III. The possible site of action of verapamil. Biochem Pharmacol 26: 735-740

38. Somers G, Devis G, Malaisse WJ (1976) Analogy between native and exogenous ionophores in the pancreatic B-cell. FEBS Lett $66: 20-22$
39. Malaisse WJ, Devis G, Somers G (1977) Inhibition by verapamil of ionophore-mediated calcium translocation. Experientia 33: 1035-1036

40. Malaisse WJ (1979) Protective effect of calcium against the verapamil-induced inhibition of ionophore-mediated calcium translocation. Experientia 35: 1578-1579

41. Malaisse WJ, Somers G, Valverde I, Couturier E (in press) Organic calcium-antagonists and calcium-ionophores. Arzneimittelforsch

42. Malaisse WJ, Sener A, Devis G, Somers G (1976) Calciumantagonists and islet function. V. Effect of R33711. Horm Metab Res 8: 434-438

43. Malaisse WJ, Couturier E (1978) Ionophoretic model for NaCa countertransport. Nature 275: 664-665

44. Brisson GR, Malaisse WJ (1971) Insulinotropic effect and possible mode of action of a new potent sulfonylurea (BS-4231). Can J Physiol Pharmacol 49: 536-544

45. Linden J, Brooker G (1978) The positive insulinotropic action of sulfonylureas. A mechanism independent of cyclic adenosine 3', 5'-monophosphate. Diabetes 27: 694-698

46. Verry M, Bryon PA, Dechavanne $M$, Lagarde $M$, Vainer $H$ (1975) Etude des phénomènes biochimiques du métabolisme plaquettaire. Le gliclazide, agent régulateur de la physiologie plaquettaire. J Pharmacol Clin 2: 199-208

Received: May 19, 1980

W. J. Malaisse

Laboratory of Experimental Medicine

Brussels Free University

115 Bvd. de Waterloo

B-1000 Brussels

Belgium 